\title{
EFFECT OF ADDITION OF VARIOUS ORGANIC MATTERS TO BAITED TRAPS ON THE NUMBER OF CAPTURED RHINOCEROS BEETLES
}

\author{
HASHEM, H.H. ${ }^{1}$, OLFAT E. ARAFA ${ }^{1}$, M.M.EL-ZOHAIRY ${ }^{2}$ AND \\ M.A. EL-DEEB ${ }^{2}$ \\ 1. Plant Protection Research Institute, ARC, Zagazig, Sharkia. \\ 2. Plant protection Department, Faculty of Agriculture, Zagazig University
}

(Manuscript received 13 October 2008)

\begin{abstract}
The effect of various organic matters to add to baited traps, on the number of captured rhinoceros beetles was studied under field conditions, at El-Kassassen district.

1. Cattle dung Results obtained could be summarized as follows:-

The total numbers of different stages (eggs, larval, pupae and adults) in pits were increased during April, July and September and it had three peaks in seasons 1998 and 1999.

\subsection{Pigeon dung}

The total numbers of different stages (eggs, larval, pupae and adults) in pits were increased during April, July, and September and it had three peaks in seasons 1998 and 1999.

\subsection{Chicken dung}

The total numbers of different stages (eggs, larval, pupae and adults) in pits were increased during April, July, and October and it had three peaks in seasons 1998 and1999.

\subsection{Preference of organic matter additions}

The highest counts in pits supplied with cattle dung (24163 individual) followed by pits supplied with pigeon (17862 individual) and the least recorded in chicken (2290 individual).

The results can help us to recommend that the cattle dung is the most preferable organic matter addition in pits to attract or rear this pest and to monitor the level of population .
\end{abstract}

\section{INTRODUCTION}

Date palm trees are liable to be attacked by many insect pests and diseases, the namely Oryctes spp. and Phyllognathus excavatus Forster which cause a serious damage at roots, trunks, leaves and fruits resulting in economic loss to date fruits yield. The first record of these peaks on date palm plantations of Sharkia and Ismailia Governorates was achieved by Alfieri (1976) and Shalaby (1958) in the MOA collection, Plant Prot. Res. Institute.

Although various studies have been conducted on Oryctes spp. and Phyllognathus spp.in other countries by authors such as Demel (1931) Kunhi kannan(1931),Corbett(1932),Jepson(1933and1935), Alibert(1938) , Cherian and Anantanarayanan (1939) Frappa (1939), Gressitt(1953), Cumber(1957), Bedford (1968 and 1976), Monty (1978), Lohar andMecci (1985), Reynolds (1988). 
Little work has been done on Oryctes spp. and Phyllognathus spp. In Egypt, special stress, however has been laid by Hafez and Bishara (1961) on Pentodon bispinosus.

Therefore, it was found expecdient that a detailed study on ecology of Oryctes spp. and Phyllognathus spp. adult under field conditions in newly reclaimed areas at El- kassassen district, Ismailia Governorates is necessary.

\section{MATERIALS AND METHODS}

The experiments were carried out during two successive seasons, 1998 and 1999 .In field area, an area of 80 feddans at Gala farm, sabri village, Kassessen district, Ismailia Governorate.

Different types of baited traps were applied for attracting rhinoceros beetles of both Oryctes spp and Phyllognathus excavatus Forester adults and their immature stages. Five round pits ( $80 \mathrm{~cm}$ depth $\times 40 \mathrm{~cm}$ diameter) a part $83 \mathrm{~cm}$. from date palm trees. Every pit was provided with organic manure (cattle dung) at the depth of 80 $\mathrm{cm}$. and irrigated weekly during the two experimental years. Pits were examined weekly in the morning and the catches of different stages (eggs, larval, pupae and adults) were collected, identified, counted and sexed.

\section{RESULTS AND DISCUSSION}

\section{Addition of various organic matters to baited traps.}

\subsection{Cattle dung}

Data obtained in Table (1) revealed that the total number of different stages (eggs, larval, pupae and adults) in pits was increased during April, July and September and it had three peaks during 1998 and1999 seasons. These results are in agreement with that finding by Reynolds (1998) who states that cattle can cause damage to young trees, and cattle dung may serve as a breeding place for rhinoceros beetle (Oryctes rhinoceros, L.) a major pest of coconut.

\subsection{Pigeon dung}

Data obtained in Table (1) studied that the total number of different stages (eggs, larval, pupae and adults) in pits was increased during April, July and September and it had three peaks during 1998 and1999 seasons.

\subsection{Chicken dung}

Data obtained in Table (1) recorded that the total number of different stages (eggs, larval, pupae and adults) in pits were increased during April, July and October and it had three peaks during 1998 and1999 seasons. These results are in agreement with the finding of Jepson (1935) in Colombo studied that larvae of Phyllognathus 
dionysius, F., and Oryctes rhinoceros, L., were found together in green manure around the base of young coconut palms had been severely damaged by the latter. Lohar and Mecci (1985) mentioned the Scarabaeidae of the campus of Sind. Agricultural University in Tandojam, Pakistan, were sampled in dung, fallow soils and field crops between June and December. Oryctes rhinoceros maximum numbers were collected in June- August.

\section{Preference of organic matter additions}

Data obtained in Table (1) revealed that the highest counts in pits supplied with cattle dung (24163 individual) followed by pits supplied with pigeon (17862 individual) and the least recorded in chicken(2290 Individual).

The results can help us to recommend that the cattle dung is the most preferable organic matter addition in pits to attract this pest and to monitoring the level of population or to rear under laboratory condition. These results are in agreement with the finding of Nirula et al. (1952) who stated that the preferred breeding medium to $O$. rhinoceros was cattle dung, and eggs were not laid in coir dust or in coconut husks that were mulched and buried or left to decompose in the open for over three months.

Table 1. Monthly average number of Oryctes spp. and Phyllognathus excavatus adult and their different stages (eggs, larval, pupae and adults) attracted to five pits as baited traps ,supplied cattle dung, pigeon dung and chicken dung , sited under date palm trees orchard,at El-Kassessen district, Ismailia Governorate during two seasons 1998 and 1999.

\begin{tabular}{|l|c|c|c|c|c|c|c|c|c|}
\hline \multirow{2}{*}{ Date } & \multicolumn{3}{|c|}{ Cattle dung } & \multicolumn{3}{c|}{ Pigeon dung } & \multicolumn{3}{c|}{ Chicken dung } \\
\cline { 2 - 11 } & 1998 & 1999 & total & 1998 & 1999 & total & 1998 & 1999 & total \\
\hline Jan & 0 & 192 & 192 & 0 & 122 & 122 & 0 & 27 & 27 \\
\hline Feb & 0 & 13 & 13 & 0 & 12 & 12 & 0 & 3 & 3 \\
\hline March & 0 & 1495 & 1495 & 0 & 960 & 960 & 0 & 124 & 124 \\
\hline April & 2729 & 2012 & 4741 & 1943 & 1518 & 3461 & 236 & 187 & 423 \\
\hline May & 974 & 885 & 1859 & 694 & 660 & 1354 & 109 & 82 & 191 \\
\hline June & 462 & 1165 & 1627 & 326 & 916 & 1242 & 45 & 112 & 157 \\
\hline July & 2539 & 1697 & 4236 & 2007 & 1373 & 3380 & 200 & 120 & 320 \\
\hline Aug & 740 & 743 & 1483 & 626 & 596 & 1222 & 57 & 59 & 116 \\
\hline Sept & 1733 & 1715 & 3448 & 1245 & 1168 & 2413 & 149 & 108 & 257 \\
\hline Oct & 1343 & 1133 & 2476 & 1031 & 877 & 1908 & 139 & 164 & 203 \\
\hline Nov & 747 & 636 & 1383 & 507 & 604 & 1111 & 156 & 112 & 268 \\
\hline Dec & 570 & 640 & 1210 & 407 & 270 & 677 & 55 & 46 & 101 \\
\hline Total & 11837 & 12326 & 24163 & 8786 & 9076 & 17862 & 1146 & 1144 & 2290 \\
\hline
\end{tabular}




\section{REFERENCES}

1. Alfieri, A. 1976. The Coleoptera of Egypt. Bull. Soc. Ent. Egypt, 5: 217.

2. Alibert, H. 1938. Etude sur les insects parasites du palmier à huile au Dahomey. Rev. Bot. Appl., 207 (18): 745 - 773.

3. Bedford, G.O. 1968. Observations on the ecology of Oryctes (Coleoptera: Scarabaeidae: Dynastinae) in Madagascar. Bull. Ent. Res. 58 (1): 83 - 105.

4. Bedford, G.O. 1976. Rhinoceros beetles in Papua New Guinea. South Pacific Bulletin, 26 (3): $38-41$

5. Cherian, M.C. and K.P. Anantanarayanan. 1939. Studies on the coconut palm beetle (Oryctes rhinoceros Linn.) in South India. Indian J. Agric. Sci. ,3 (9): 541 559.

6. Corbett, G.H. 1932. Entomological Notes. First Quarter. Malayan Agric. J., xx (4): $185-186$.

7. Cumber, R.A. 1957. Ecological studies of the Rhinoceros Beetle Oryctes rhinoceros (L.) in Western Samoa. Tech. Pap. S. Pacif. Comm., vi (107): 32.

8. Demel, C.N.E.J. 1931. Habits and control of the coconut black beetle Oryctes rhinoceros (L.) Trop. Agriculturist, Lxxvii (2): 99 - 111.

9. Frappa, C. 1939. Contribution à L’étude des Oryctes des Madagascar. Bull. écon. Macâ giscar (N.S.), (12): $344-378$.

10. Gressitt, J.L. 1953. The coconut rhinoceros beetle (Oryctes rhinoceros) with particular reference to the Palau Islands. Bull. Bishop Mus., viii (212): 157.

11. Hafez, M. and S.I. Bishara. 1961 a. Studies on the biology and ecology of Pentodon bispinosus (Kust.) in Egypt. I - the adult stage (Coleoptera: Scarabaeidae: Dynastinae). (with 2 text figures) Bull. Soc. Ent. Egypt, xlv: 155 177.

12. Jepson, E.P. 1933. Report on the work of the Division of Plant Pest Control. Adm. Rep. Div. Agric., $107-115$.

13. Jepson, E.P. 1935. Report on the work of the Division of Plant Pest Control. Adm. Rep. Div. Agric., $104-124$.

14. Kunhi Kannan, K. 1931. Ground grubs and their movements in the soil. J. Mysore Agric. Exp. Un., xii (1): $3-4$. 
15. Lohar, M.K. and A.K. Mecci. 1985. Occurrence and habits of scarab beetles. Pakistan Journal of Agricultural Research, 6 (1): 49 - 54.

16. Monty, J. 1978. The coconut palm rhinoceros beetle, Oryctes rhinoceros (L.) (Col., Dynastidae) in Mauritius and its control. Revue Agricole et sucrière de I'lle Maurice, 57 (2): $60-76$.

17. Nirula, K.K., J. Antony and K.P.V. Menon. 1952. Investigations on the pests of the coconut palm. (1) The rhinoceros beetle (Oryctes rhinoceros). control of grubs of Oryctes rhinoceros. Indian Cocon. J. 4 (1): $5-12,34-35$.

18. Reynolds, S.G. 1988. Some factors of importance in the integration of pastures and cattle with coconuts (Cocos nucifera). Journal of Biogeography, 15 (1): 31 39.

19. Shalaby, F. 1958. Alphabetical list of Egyptian insects in the collection of MOA. Tech. Bull., $135-284$. 
تأثير أنواع المواد العضوية المضافة إلى حفر المصائد الجاذبة على مجموع الأعداد المصادة من حشرات جعل النخيل

حليم حسن هاثم'، الفت السيد عرفة'، منصور محمد الزهيرى'، محمد على الايب '

$$
\begin{aligned}
& \text { - } 1 \text { - معرة بحوث وقاية النباتات-مركز البحوث الزراعية - الزقازيق -الشرقية } \\
& \text { r- قسم وقاية النبات - كلية الزراعة - جامعة الزقازيق }
\end{aligned}
$$

تمت هذة الدراسات بمزرعة الجلا بعزبة صبرى بمنطقة القصاصين محافظة الإسماعيلية

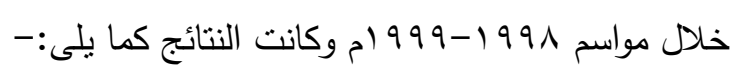

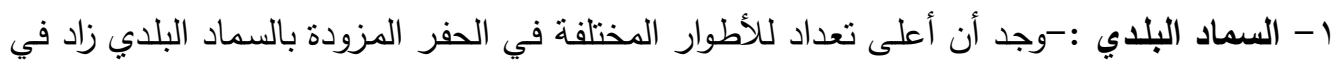

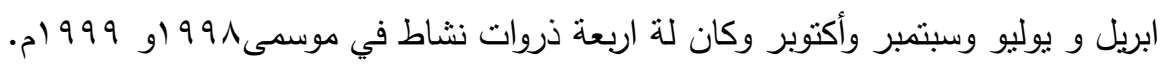

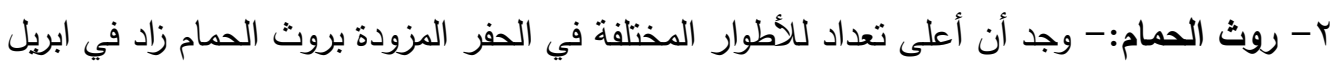

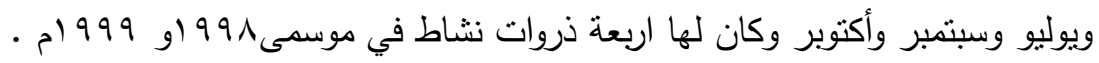

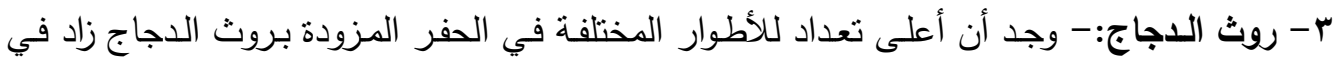

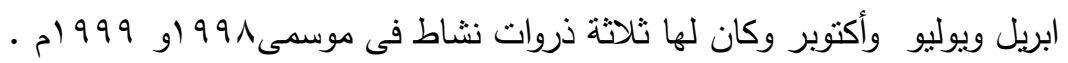

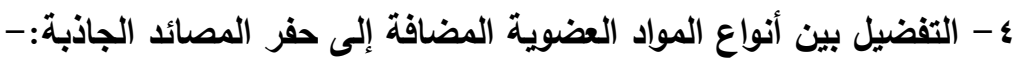

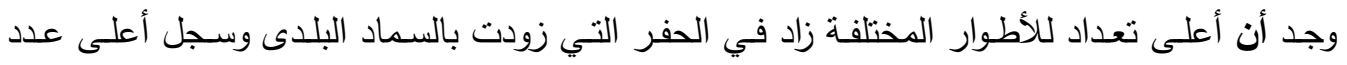

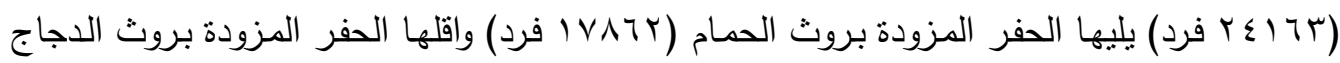

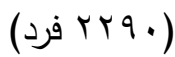

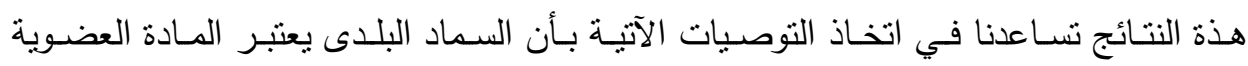

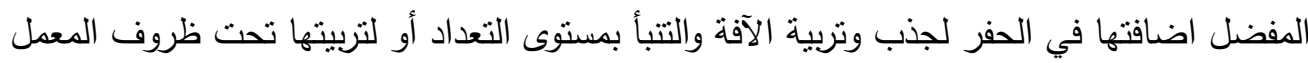

